\title{
Violetta BORECKA
}

Uniwersytet w Białymstoku

violetta.borecka@wp.pl

\section{PSYCHOLINGWISTYCZNE PRZYCZYNY FOSYLIZACJI W NAUCE JEZZYKA ANGIELSKIEGO}

\section{WPROWADZENIE}

„Moi uczniowie w ogóle się nie uczą! Przez kilka lat ćwiczę z nimi Present Simple, a oni ciągle popełniają te same błędy. Ile razy mam tłumaczyć, że I doesn't like school nie jest po angielsku?! Chyba jestem beznadziejnym nauczycielem...". Autor tej wypowiedzi nie jest odosobniony w swoim przekonaniu. Nauczyciele języka angielskiego postrzegają niskie osiągnięcia uczniów jako porażkę swoich umiejętności dydaktycznych i metodycznych, a nad problemem „nieuczenia się" ubolewa znaczna część glottodydaktyków. Narzekają, że ich rola ogranicza się do dwóch czynności: nauczania kilku (ciągle tych samych) zagadnień lingwistycznych, a później korekty (ciągle tych samych) błędów. Działania bardziej zdeterminowanych pedagogów zmierzające do podniesienia poziomu poprawności językowej poprzez zwiększanie ilości materiału dydaktycznego, wprowadzanie różnorodnych technik nauczania oraz podnoszenie świadomości językowej uczniów przynoszą krótkotrwały efekt terapeutyczny. Progresja interjęzyka w kierunku prawidłowych struktur jest tymczasowa: po pewnym czasie znaczna część błędów pojawia się ponownie i ulega utrwaleniu na zawsze.

Celem artykułu jest przypomnienie podstawowych założeń hipotezy fosylizacji $\mathrm{w}$ nauce języka obcego i omówienie wybranych psycholingwistycznych przyczyn tego zjawiska na przykładzie polskich uczniów uczących się języka angielskiego w końcowym etapie kształcenia ogólnego. Materiału badawczego dostarczył autorski projekt edukacyjny reali- 
zowany w latach 2013-2016 w Technikum Handlowo-Ekonomicznym w Białymstoku. Z zebranego korpusu wypowiedzi pisemnych $w$ języku angielskim, wyekscerpowano błędy językowe o cechach stabilizacji, które zostały poddane analizie oraz posłużyły jako przykłady omawianego zjawiska. Artykuł stanowi głos w dyskusji nad przyczynami „nieuczenia się” pewnych elementów leksykalno-gramatycznych wśród polskich uczniów oraz zwraca uwagę na silny związek fosylizacji błędów z multiplikacją zjawisk inter- i intralingwalnych.

\section{FOSYLIZACJA JAKO KLUCZOWA CECHA INTERJĘZYKA}

Rozważania na temat fosylizacji należy rozpocząć od przypomnienia teorii interjęzyka. Termin interjęzyk (ang. interlanguage) został wprowadzony przez amerykańskiego lingwistę Larry'ego Selinkera (1972: 214), który zauważył, że osoba ucząca się języka obcego, w celu realizacji receptywnych i produktywnych sprawności językowych, wykorzystuje reguły swojego języka ojczystego i kompilując je z poznawanymi regułami języka drugiego, przekształca je w zupełnie odrębny, abstrakcyjny, ale funkcjonalny system gramatyczny. Taka wewnętrzna gramatyka zachodzi ciągłym zmianom wskutek interlingwalnych oraz intralingwalnych identyfikacji.

Unikalną własnością interjęzyka jest jego zdolność do fosylizacji (ang. fossilization) (Adjemian 1976), którą definiuje się jako permanentne zaprzestanie rozwoju pewnych elementów strukturalnych, reguł i zjawisk językowych pomimo zdolności ucznia, jego motywacji do nauki oraz akulturacji w środowisku docelowym (Selinker i Lamendella 1978). Próbując wyjaśnić mechanizm fosylizacji, Selinker założył istnienie ukrytej w mózgu struktury psychologicznej (ang. latent psychological structure), aktywującej się wskutek działania pięciu psycholingwistycznych procesów: transferu języka ojczystego, hipergeneralizacji reguł języka docelowego, transferu nauczania, strategii uczenia się oraz strategii komunikowania ${ }^{1}$. Brak kognitywnego dostępu do właściwej jednostki w języku

\footnotetext{
1 Struktura językowa, będąca biologicznym odpowiednikiem gramatyki uniwersalnej, występuje naturalnie $\mathrm{w}$ umyśle niemowlęcia i zanika $\mathrm{w}$ miarę procesu dorastania (Lenneberg 1967 za: Ellis 1995: 44). Selinker pod wpływem badań Lenneberga nad akwizycją języka ojczystego założył, że równolegle do ukrytej struktury językowej (ang. latent language structure) musi istnieć ukryta struktura psychologiczna (Selinker 2006: 201).
} 
docelowym powoduje wykorzystanie alternatywnej jednostki języka ojczystego lub interjęzyka. Uruchomienie ukrytej struktury psychologicznej prowadzi do „zamrożenia” kompetencji językowej na pewnym poziomie i objawia się charakterystyczną nienatywnościa norm języka docelowego (Selinker 2006: 201). Lightbown (2000: 179) sugeruje, że fosylizacja następuje w momencie, gdy uczeń zaspokoi swoja potrzebę komunikacji oraz/lub integracji w społeczności języka docelowego. Fosylizacji mogą ulegać struktury językowe na różnych poziomach organizacji języka: fonologicznym, morfologicznym, syntaktycznym, leksykalno-semantycznym i pragmatycznym (Selinker 1992: 247). Zjawisko to jednak nie ma charakteru globalnego - zatrzymanie przyswajania pewnych elementów gramatyki nie utrudnia dalszego prawidłowego ewaluowania innych kompetencji językowych np. w obszarze leksykalnym. Z punktu widzenia glottodydaktyki istotną cechą permanentnej stabilizacji ${ }^{2}$ jest długotrwałe zaprzestanie rozwoju cech interjęzyka wbrew woli uczącego się (Larsen-Freeman 2006: 190).

Dyskusję o fosylizacji i jej roli $\mathrm{w}$ kształtowaniu interjęzyka podjęło wielu badaczy ${ }^{3}$, a ich wnioski wzbogaciły literaturę przedmiotu. Fosylizacja została uznana kluczową cechą akwizycji języka obcego rozróżniającą naukę języka pierwszego od kolejnych (Bley-Vroman 1989: 45), jednak brakuje jej prostych definicji - opisywano ją zarówno jako proces, jak i produkt, jako eksplanans, jak i eksplanandum (Long 2003). Kluczowy problem badawczy zjawiska fosylizacji nie leży oczywiście w trudnościach związanych z precyzyjnym i jednoznacznym zdefiniowaniem tego pojęcia, lecz krąży wokół poszukiwania odpowiedzi na pytanie: gdzie leży granica między stabilizacją błędu a jego permanentną fosylizacją i dlaczego niektóre struktury interjęzyka zaprzestają się rozwijać i ulegają fosylizacji, a inne nie (mimo że są obiektywnie trudniejsze).

2 Fosylizacja tymczasowa, określana mianem stabilizacji, odnosi się do etapu językowego plateau, na którym kompetencja językowa pozostaje w niezmienionym poziomie przez pewien czas. Istnieje jeszcze szansa przejścia na kolejny, wyższy etap rozwoju interjęzyka. Często jednak eliminacja nieprawidłowych struktur jest pozorna, gdyż błędy, które wydawały się zwalczone, w pewien sposób są dalej obecne w mózgu, przechowywane przez mechanizm fosylizacji. Następuje wtedy fosylizacja permanentna, będąca rezultatem wielu interaktywnie działających czynników (Han 2003: 100).

3 Zagadnieniem tym zajmowali się m.in. Ellis (1995, 2000), Han (2003), Kellerman (1989), Larsen-Freeman (2006), Lightbown i Spada (1999), Odlin (1989), Schachter (1990), Tarone (2006, 2014), White (2003). 


\section{ZASADA MULTIPLIKACJI EFEKTÓW}

Wyniki badań prowadzonych przez Selinkera i Lakshmanan (1992) zaowocowały ciekawymi, z punktu widzenia akwizycji języka obcego, wnioskami. Wysnuto hipotezę, że wpływ pojedynczego procesu kognitywnego (np. hipergeneralizacji bodźca) w izolacji od innych może wywołać efekt stabilizacji błędu, ale w dalszym ciągu, przy sprzyjających okolicznościach, możliwe jest przezwyciężenie trudności. Innymi słowy, przy pomocy stosownych działań pedagogicznych lub podnosząc świadomość językową ucznia, można doprowadzić do destabilizacji błędnej struktury. Dopiero współdziałanie dwóch (lub większej ilości) czynników skutkuje większym zagrożeniem stabilizacja form interjęzyka prowadzaca do fosylizacji. Odkrycie to nazwane zasadą multiplikacji efektów ${ }^{4}$ (ang. Multiple Effects Principle) skłoniło autorów do rozważań nad siłą czynników wpływających na utrwalanie błędów. Zauważyli oni, że mechanizm fosylizacji determinowany jest w pierwszej kolejności przez transfer językowy. Proces ten charakteryzuje się wyjątkową zdolnością generowania opornych na nauczanie struktur $\mathrm{w}$ interjęzyku, a $\mathrm{w}$ tandemie $\mathrm{z}$ innym procesem doprowadza do silnego zagrożenia fosylizacją. Stąd kolejny element hipotezy stanowi, że: transfer językowy jest uprzywilejowanym (staba forma hipotezy) lub niezbędnym (silna forma hipotezy) parametrem w konfiguracji wplywów (Selinker i Lakshmanan 1992: 198-199).

Selinker (1992: 247) konkluduje, że kompilacja procesów z transferem $\mathrm{w}$ roli prymarnej daje całkowicie skamieniała kompetencje językowa, która bez względu na starania ucznia czy jego nauczyciela trwale zahamują proces nauki pewnych elementów językowych. Z tego względu pedagogiczną implikacją zjawiska multiplikacji jest brak możliwości destabilizacji struktur o cechach fosylizacji przez strategie podnoszenia świadomości (Selinker i Lakshmanan 1992: 199). Mimo że zawsze istnieje potencjał do nauki pewnych powierzchniowych aspektów języka takich jak słownictwo, to koncepcyjne rozumienie języka nie ma szans na poprawę. Dodaje również, że inne zmienne, takie jak wiek pierwszego kontaktu z językiem docelowym, długość okresu nauki czy czas pobytu w kraju języka docelowego, nie mają większego znaczenia $\mathrm{w}$ procesie stabilizacji niepoprawnych struktur interjęzyka (Selinker 1993: 24). Podobnego

\footnotetext{
4 Wszystkie tłumaczenia z języka angielskiego na język polski zostały wykonane przez autorkę referatu.
} 
zdania jest Zybert (1999: 175), który twierdzi, iż fosylizacja błędów językowych następuje bez względu na aktualny wiek ucznia, ilość i rodzaj wyjaśnień, ekspozycję na dodatkowe dane językowe czy nowe techniki nauczania.

\section{OPIS BADANIA}

Jako nauczyciel i egzaminator odnotowuję niepokojącą skłonność polskich uczniów do permanentnego tworzenia abstrakcyjnych struktur leksykalno-gramatycznych według pewnych utartych schematów, niezgodnych jednak z normami języka angielskiego. Na bazie długofalowej obserwacji uczestniczącej postawiłam tezę, iż interjęzyk uczących się posiada cechy selektywnej fosylizacji, co w znacznym stopniu skutkuje zaprzestaniem rozwoju kompetencji językowo-komunikacyjnych. W związku z powyższym podjęłam próbę zbadania tego zjawiska i sformułowałam następujące pytania badawcze:

(1) Czy w interjęzyku polskich uczniów uczących się języka angielskiego na poziomie szkoły ponadgimnazjalnej (w zakresie wypowiedzi pisemnych) można odnaleźć cechy trwałej fosylizacji językowych struktur leksykalno-gramatycznych?

(2) Jakie czynniki determinują utrwalanie tych błędów?

(3) Czy istnieją szanse na opóźnienie procesu trwałej fosylizacji błędnych struktur?

Badana grupa składała się z grupy 15 uczniów technikum, o zbliżonym poziomie intelektualnym oraz czasie ekspozycji na język angielski ${ }^{5}$, posługujących się tym samym językiem ojczystym (polskim). Przez cały czteroletni cykl nauczania od września 2013 do lutego 2017 roku prowadziłam autorski projekt badawczo-edukacyjny polegający na przeprowadzaniu, ocenianiu oraz archiwizowaniu wypowiedzi pisemnych (listów prywatnych i formalnych, rozprawek, opisów, opowiadań, zaproszeń, ogłoszeń, wiadomości na forum internetowym) uczniów. Testy przeprowadzałam regularnie raz w miesiącu przez cztery kolejne lata edukacji. Za każdym razem zadaniem uczniów było zredagowanie wypowiedzi

\footnotetext{
5 Wszyscy uczniowie rozpoczęli obowiązkową naukę języka angielskiego w roku 2008, żaden $z$ nich nie uczęszczał na dodatkowe zajęcia języka angielskiego przed okresem formalnej nauki w szkole ani w jej trakcie.
} 
o tematyce bliskiej problemom współczesnych nastolatków. Wymagania leksykalne oraz gramatyczne w zadaniu korespondowały z podstawą programową kształcenia ogólnego dla czwartego etapu edukacyjnego (dom, szkoła, człowiek, sport, świat przyrody, itd.) ${ }^{6}$. Po każdorazowym sprawdzeniu prac i wspólnej z uczniami analizie najczęściej powtarzających się błędów przeprowadzałam różnorodne zabiegi dydaktyczne polegające zarówno na ponownym wyjaśnianiu problematycznego materiału językowego, jak i ćwiczeniach repetycyjnych oraz wprowadzeniu większej ilości danych językowych.

\section{WYNIKI BADAŃ}

W oparciu o zebrany materiał badawczy dokonałam analizy błędów na płaszczyźnie leksykalno-gramatycznej. W korpusie wyodrębnionych błędów zauważyłam osobliwą konsekwencję polegającą na cyklicznym powtarzaniu pewnych niepoprawnych, z punktu widzenia norm języka angielskiego, struktur i reguł. Jestem przekonana, że błędy te mają cechy trwałej stabilizacji, gdyż mimo usilnych działań dydaktycznych, regularnej ekspozycji uczniów na nowe dane językowe, stosowania zróżnicowanych technik nauczania, pozytywnego motywowania i zachęcania do świadomej aktywności językowej zauważyłam, że przez 4-letni okres nauki w technikum pewne elementy języka ucznia pozostają $\mathrm{w}$ niezmienionym kształcie. Podobnymi spostrzeżeniami dzielą się za mną inni nauczyciele języka angielskiego, którzy twierdzą, że językowo-komunikacyjne kompetencje ich uczniów rozwijają się zaledwie w minimalnym zakresie, nieproporcjonalnym do włożonej pracy zarówno przez nauczyciela, jak i samych uczniów. Takie „nieuczenie się” następuje bez względu na poziom motywacji ucznia, jego ambicje osobiste i plany zawodowe. Wszystkie wyodrębnione $\mathrm{z}$ materiału badawczego powtarzające się błędy posiadają cechy powierzchniowe wskazujące na silny wpływ języka polskiego. Są one łatwe do zidentyfikowania przez nauczyciela posługującego się tym samym językiem ojczystym co jego uczniowie. Zasada multiplikacji efektów uznaje transfer językowy za niezwykle istotny czynnik wpły-

\footnotetext{
6 Rozporzadzenie Ministra Edukacji Narodowej z dnia 27 sierpnia 2012 r. w sprawie podstawy programowej wychowania przedszkolnego oraz kształcenia ogólnego w poszczególnych typach szkót, https://men.gov.pl/wpcontent/uploads/2011/02/zalaczniknr4.pdf, dostęp: 07.07.2017.
} 
wający na stabilizację błędów - w pierwszej kolejności skrótowo omówię ten proces.

\subsection{STRATEGICZNY CZYNNIK FOSYLIZACJI - TRANSFER JĘZYKOWY}

Transfer językowy, uznany za uprzywilejowany, a nawet niezbędny czynnik fosylizacji należy rozumieć jako skłonność do przenoszenia uprzednio opanowanych wzorców struktur z języka ojczystego, a także sposobów ich realizacji na aktualnie przyswajany materiał językowy (Od-

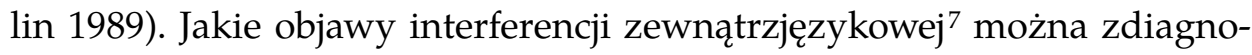
zować w interjęzyku polskiego ucznia? Charakterystyczne cechy wypowiedzi to: dosłowne tłumaczenie związków frazeologicznych z języka polskiego na angielski (kalka syntaktyczna), brak uporządkowania składniowego typowego dla języka angielskiego (SVO), przenoszenie złożonych związków syntaktycznych z języka polskim na język angielski, pomijanie podmiotów, naruszanie zasad pozycjonowania okoliczników oraz dopełnień, używanie zapożyczeń z języka polskiego. W jednym zdaniu często zauważamy błędy, które posiadają cechy wewnątrzi zewnątrzjęzykowe (ortograficzne, interpunkcyjne), błędy leksykalne łączą się z gramatycznymi i dalej wpływają na kolejne zmiany struktur. Wszystkie te innowacje nierzadko doprowadzają do problemów natury pragmatycznej.

Aby w obrazowy sposób przedstawić problem kalki syntaktycznej, przytoczę kilka przykładów realizacji polecenia Zaproponuj koledze wspólne wyjście do kina w najbliższy weekend ${ }^{8}$. Można zauważyć, że wypowiedzi odzwierciedlają proces przekładu zachodzący w umyśle ucznia, który najpierw mentalnie tworzy komunikat $\mathrm{w}$ języku polskim, a następnie tłumaczy go "słowo-po-słowie" na język angielski.

*In saturday I invite you to the cinema9.

PL: W sobotę zapraszam cię do kina.

7 Zamiennie zwanej międzyjęzykową, zewnątrzjęzykową lub interlingwalną.

8 Sugerowana realizacja polecenia w języku angielskim: Shall we go to the cinema on Saturday? / We could go to the cinema on Sunday. / Why don't we go to the cinema at the weekend? / What about going to the cinema on Friday evening? / Let's go to the cinema tomorrow, etc.

9 Wszystkie przykłady błędnych wypowiedzi (z gwiazdką *) są cytowane w wersji oryginalnej i dlatego oprócz omawianych problemów językowych mogą w nich wystąpić również inne błędy, których artykuł nie dotyczy lub są aktualnie nieporuszane. 
*Maybe tomorrow go to the cinema?

PL: Może jutro pójdziemy do kina?

*I propose you together going to cinema in nearest weekend.

PL: Proponuję ci wspólne wyjście do kina w najbliższy weekend.

Należy podkreślić, że obecnie na lekcjach języka angielskiego konstrukcje typu: sugestie, propozycje, zapraszanie, itp. należą do tzw. podstawy programowej, którą uczeń zobowiązany jest opanować, a nauczyciel realizować. W konsekwencji prawie każda wypowiedź ucznia (pisemna czy ustna) będzie zawierała elementy wymienionych konstrukcji. Nauczyciel również przypomina, że jeśli uczniowie dokonują tłumaczeń, to nie powinny one być dosłowne. Często sugeruje uczniom zastąpienie nieznanego słowa lub zwrotu innym lub podobnym. Polecenia $\mathrm{w}$ zadaniach przekazane są $\mathrm{w}$ taki sposób, aby dać szansę na prawidłowy przekład pod względem leksykalnym i gramatycznym, bez wymuszania na uczniach stosowania zwrotów, których nie znają, i w konsekwencji stosowania rozwiązań poprzez skojarzenia z językiem ojczystym. Mimo to w wielu uczniowskich sformułowaniach zauważa się wysoki stopień interferencyjności, co świadczy o silnym wpływie transferu niezależnym od podejmowanych działań dydaktyczno-metodycznych.

\subsection{MULTIPLIKATYWNE CZYNNIKI FOSYLIZACJI - SYMPLIFIKACJA I HIPERGENERALIZACJA REGUŁ}

Zgodnie z zasadą multiplikacji efektów permanentna stabilizacja błędnych struktur w interjęzyku ucznia powstaje wskutek multiplikacji procesu interferencji interlingwalnej oraz innych addytywnych czynników. Jakich kognitywnych procesów (odmiennych od transferu) można doszukać się w niepoprawnych wypowiedziach polskich uczniów? Uczeń dysponuje nie tylko wiedzą swojego języka ojczystego, ale także aktualnie przyswajaną (choć ograniczoną) wiedzą języka docelowego. Aby pozornie zwiększyć kompetencje umożliwiające porozumiewania się w języku obcym, będzie on podejmował pewne świadomie lub nieświadome działania intralingwalne (Ellis 1995: 171-172). Objawiają się one szczególnie w postaci symplifikacji oraz hipergeneralizacji reguł języka docelowego. 
5.2.1. SYMPLIFIKACJA

Symplifikacja (ang. simplification) jest niezależna od narodowości i wpływu międzyjęzykowego ${ }^{10}$ i ujawnia się w obrębie języka docelowego (Odlin 1989: 41). Wynika ona z przekonania, że opuszczenie pewnych elementów, takich jak przedimek, końcówka fleksyjna, zaimek osobowy, etc. nie zakłóci przekazu, gdyż inne elementy, np. okolicznik czasu, liczebnik czy osoba, uzupełnią jego znaczenie semantyczne. Stąd takie upraszczanie struktur nazywane jest redukcją redundantną (Schachter: 1990).

$\mathrm{Z}$ wypowiedzi Polaków najczęściej wyłania się redukcja redundantna przedimków. Prawidłowe użycie określników a/an, the jest dla nas najbardziej skomplikowanym zagadnieniem gramatycznym w języku angielskim. Chociaż system języka polskiego nie posiada przedimków, Arabski (2007) i Zybert (1999) opisują pomijanie ich jako skutek pasywnej interferencji struktur języka polskiego. Redukcja tej kategorii gramatycznej zachodzi w sposób selektywny. Pewne wyrażenia, które wcześniej zostały opanowane na pamięć (go to the cinema, listen to the radio, I've got a dog) mogą zawierać prawidłowo zastosowane określniki. Natomiast tam, gdzie uczeń dokonuje prawdopodobnie bardziej świadomego tłumaczenia z języka polskiego, pojawią się redukcje. Jako ilustrację tego zjawiska zaprezentuję kilkuzdaniową wypowiedź:

${ }^{*}$ I moved from $\sqrt{ }$ city to $\sqrt{ }$ countryside. There are two sides. I like $\sqrt{ }$ village. Before we lived in $\sqrt{ }$ small flat. Now we live near $\sqrt{ }$ forest in $\sqrt{ }$ big house. I've got a dog and $\sqrt{ }$ rabbit. I've got a new friend. My mother relaxes in a garden. My father has got a garage. When we moved I broke $\sqrt{ }$ lamp. (...) I'm going to change $\sqrt{ }$ colour of my room. (...). I don't like $\sqrt{ }$ new place because I can't go to the cinema every week or to the theatre.

Pomijanie przedimków nie jest domeną tylko „słabych" uczniów. Także ci, których kompetencja językowa ewoluowała na wyższy poziom i rozwija się $\mathrm{w}$ prawidłowym kierunku, dokonują redukcji. W poniższych przykładach widzimy wyrażenia zawierające bardziej skomplikowane struktury gramatyczne (np. czas Present Perfect, stronę bierną, zdania podrzędnie złożone) oraz liczne braki „a”, , an" oraz „the". Wy-

10 Tzn. nie ma związku z tym, czy taka kategoria leksykalno-gramatyczna występuje w języku ojczystym ucznia czy nie. 
nika z tego, że uczniowie mogą przechodzić na wyższe poziomy interjęzyka i jednocześnie wybiórczo „zamrażać” rozwój tych elementów, które uznają za redundantne w komunikacji w języku angielskim. Notoryczne pomijanie przedimka wydaje się świadomą strategią:

*While I was going there, I left my bag on $\sqrt{ }$ bus.

$* \sqrt{ }$ New house is situated in $\sqrt{ }$ beautiful village near the forest.

*I've just moved in and I haven't bought $\sqrt{ }$ bed yet.

*When I lived in $\sqrt{ }$ town I had $\sqrt{ }$ small flat and couldn't have $\sqrt{ }$ dog.

* $\sqrt{ }$ Book I've lost could be in $\sqrt{ }$ unpacked box.

${ }^{*} I$ have $\sqrt{ }$ absolutely wonderful flat in $\sqrt{ }$ city centre.

Opuszczanie podmiotu zdania wyrażonego zaimkiem jest kolejnym przykładem niepoprawnych struktur wynikających z symplifikacji. Redukcje dotyczą szczególnie „it” w funkcji wskazującej na remat oraz "there" występującego w konstrukcjach dopełniających (ang. expletive construction), które nie mają ekwiwalentnych odpowiedników w języku polskim i stąd są pomijane. Konsekwencją tych redukcji jest automatyczne przestawienie szyku wyrazów w wypowiedzeniu zgodne z polską normą. Zasada swobodnego pozycjonowania wyrazów obowiązująca $\mathrm{w}$ języku polskim wraz z symplifikacją polegającą na redukcji podmiotów (oraz wspominanych wcześniej przedimków) wyjaśnia mechanizm konstruowania następujących wypowiedzi:

${ }^{*}$ Here $\sqrt{ }$ is boring. (poprawnie: It's boring here.)

*In school $\sqrt{ }$ is so noisy. (poprawnie: It's so noisy at school.)

*In my room $\sqrt{ }$ is a big cupboard. (poprawnie: There's a big cupboard in my room.)

*In Warsaw $\sqrt{ }$ is a lot of shops. (poprawnie: There are a lot of shops in Warsaw.)

Kompilacja procesów transferu językowego oraz symplifikacji wydaje się tworzyć trwałe powiązania, które w sposób oczywisty będą skutkować permanentną fosylizacją. 
Symplifikacja reguł i konstrukcji czasów gramatycznych w interjęzyku ucznia objawia się silną tendencją do ignorowania cech aspektowych czasów gramatycznych takich jak dokonaność, niedokonaność, statyczność, powtarzalność czynności czy relacji z innymi częściami zdania. Opis zróżnicowanych czynności, które w języku polskim opisywane są jako teraźniejsze, dokonywany jest poprzez użycie Present Simple, np. ${ }^{*}$ learn maths a lot at the moment (poprawnie: I'm learning ...), a czynności przeszłych - poprzez Past Simple, np. *I learnt English all day yesterday (poprawnie: I was learning ...). Ignorowanie cech aspektowych często skutkuje pomijaniem markerów morfologicznych i/lub czasowników posiłkowych. Uczniowie zakładają, że wyłączenie pewnych elementów nie poskutkuje zaburzeniami komunikacji, gdyż użycie formy podstawowej czasownika oraz okoliczników czasu jest wystarczające do przybliżenia kontekstu wypowiedzi. Strategia „i-tak-się-dogadam” skutkuje następującymi wypowiedziami:

* Yesterday I spend time with my grandmother. (poprawnie: spent)

*Last Saturday my older brother have his birthday. (poprawnie: had)

${ }^{*}$ He stay in Poland for only one week. (poprawnie: is staying)

*I stay home last Monday because I feel bad. (poprawnie: was staying; felt)

*The women in the picture buying a new dress. (poprawnie: ... are buying)

* I learning for the exam since February. (poprawnie: I've been learning ...)

*They waiting here since 5 o'clock. (poprawnie: They've been waiting here for ...)

Pomijanie czasownika posiłkowego (tzw. operatora) w zdaniach pytających jest kolejnym typem redukcji powszechnie spotykanym w wypowiedziach uczniów. W języku polskim zdanie pytające często nie różni się formalnie od zdania oznajmującego, gdyż nie wymaga inwersji. W języku angielskim zarówno w pytaniach ogólnych, jaki i w pytaniach szczegółowych przed podmiotem zdania należy zwykle wprowadzić element nazywany operatorem. Polski uczeń ma trudności z produkcją prawidłowej konstrukcji pytającej ze względu na mnogość opcji (np. is, do, did, was, has, had, will, can, could, may). O ile na początku zdania ma potrzebę 
zastosowania jakiegoś elementu pytającego (uznając go za odpowiednik polskiego $c z y$ ), to $\mathrm{w}$ zdaniach pytających szczegółowych zastosuje strategię pominięcia tego zbędnego (według ucznia) elementu zdania.

*Where $\sqrt{ }$ you want to spend your holidays? (poprawnie: Where do you want ...)

*What $\sqrt{ }$ you want for dinner? (poprawnie: What do you want...)

*Why $\sqrt{ }$ he stayed at home? (poprawnie: Why did he stay...)

*How much money $\sqrt{ }$ she paid for the new smartphone? (poprawnie: How much money did she pay ...)

*When $\sqrt{ }$ you have your English exam? (poprawnie: When did you have / are you going to have / will you have / ...)

Analizując materiał badawczy, nie odnotowałam samodzielnego (niewymuszonego poleceniem) użycia pewnych czasów gramatycznych, np. Future Continuous, Present Perfect Continuous, Past Perfect Simple oraz Past Perfect Continuous, co też jest typem ukrytej symplifikacji. Biorąc pod uwagę, że konstrukcje te nie mają swojego odpowiednika w języku polskim, należy uznać, że bierna interferencja struktur ma tu również swoje odbicie. W tym zakresie fosylizacja nie objawi się w postaci błędnej produkcji form językowych, ale stagnacją rozwoju kompetencji językowo-komunikacyjnej na takim poziomie, poza który uczeń nie będzie miał szans wyjść.

\subsubsection{HIPERGENERALIZACJA REGUŁ}

Kolejną idiosynkratyczną właściwością interjęzyka zauważalną $\mathrm{w}$ wypowiedziach polskich uczniów jest hipergeneralizacja reguł (ang. overgeneralisation) - strategia polegająca na przenoszeniu wzorców wcześniej wyuczonych struktur języka obcego na aktualnie przyswajane struktury o cechach odmiennych (Ellis 2000). Zjawisko to jest także obserwowane $\mathrm{w}$ procesie nabywania języka ojczystego przez dzieci niezależnie od ich narodowości. Ucząc się języka obcego, do pewnego stopnia, podlegamy temu samemu procesowi psycholingwistycznemu, co przy nauce języka natywnego. Hipergeneralizacja świadczy o postępach w nauce. Jest dowodem na opanowanie przez uczącego się pewnych ogólnych regut występujacych w języku z pominięciem wyjątków do tych regut (Asher 1994: 1716). 
Mylna aplikacja założeń dotyczących reguł języka angielskiego najczęściej charakteryzuje się używaniem morfemu czasu przeszłego „,-ed" występującego przy czasownikach regularnych (np. played, worked, wanted) również w stosunku do czasowników nieregularnych (np. *drinked, *hitted, *goed). Niewątpliwie błąd ucznia jest dowodem na uczenie się. Uczeń, który tworzy wypowiedź ${ }^{*}$ Did you be at school yesterday? (poprawnie: Were you at school yesterday?) posiada wiedzę o budowaniu konstrukcji czasu Past Simple oraz umiejętność tworzenia zdań pytających w tym czasie. Niepoprawne *Did you be jest bezpośrednią analogią do poprawnych: Did you like ...? , Did you go ...? czy Did you take...?. Błąd polega tu na zastosowaniu fałszywej analogii i pominięciu wyjątku od reguły (formy osobowe was /were same w sobie pełnią funkcję czasownika posiłkowego).

W interjęzyku polskich uczniów permanentnie ujawniają się uogólnienia regul stosowania operatorów. Polscy uczniowie nie radzą sobie z opanowaniem podstawowych różnic między operatorami. Mają wprawdzie świadomość, że do, does (Present Simple) i did (Past Simple) występujące na początku pytania ogólnego pełnią taka samą funkcję gramatyczną jak polskie $c z y$, ale stosują je chaotycznie, nie zwracając uwagi na reguły gramatyki. W przedstawionych poniżej przykładach wyraźnie widać, że na hipergeneralizację reguły dotyczącej użycia operatora nakłada się oddziaływanie międzyjęzykowe polegające na dosłownym tłumaczeniu elementów zdania z języka polskiego:

*Do you can swim? (poprawnie: Can you swim?)

PL - Czy ty umiesz pływać?

*Did the teacher told you about the test? (poprawnie: Did the teacher tell you...?)

PL - Czy nauczyciel powiedział wam o teście?

*Does they must go with us? (poprawnie: Must they go...? / Do they have to go...?)

PL - Czy oni muszą jechać z nami?

*Does she never wasn't in a club? (poprawnie: Hasn't she ever been to a club?)

PL - Czy ona nigdy nie była w klubie?

*Don't we forgot about the food? (poprawnie: Didn't we forget...?)

PL - Czy nie zapomnieliśmy o jedzeniu? 
Językowa produkcja uczniów jest często niezrozumiała i wymaga autoryzowanej korekty. Przykłady takich hybrydowych konstrukcji syntaktycznych zaprezentowano poniżej (autorka zrezygnowała jednak z samodzielnej interpretacji treści, chociaż $\mathrm{w}$ nielogicznych na pierwszy rzut oka wypowiedzeniach, po przetłumaczeniu występujących tu okoliczników oraz słów-kluczy na język polski, można doszukać się ukrytego znaczenia):

*She don't goes after school to English classes.

*She doesn't went to the theatre. Was to the cinema.

*He doesn't been happy. He get bad mark.

*Last week we don't saw because I'm very busy.

*I'm don't like school. After I going work.

Innym typem hipergeneralizacji jest uogólnianie reguł tworzenia liczby mnogiej, które skutkuje licznymi błędami językowymi. Są one szczególnie uporczywe, gdy na proces intralingwalny (zasada dodawania "s" do rzeczownika w l.poj.) nakłada się wpływ reguły w języku polskim dotyczący tej samej kategorii gramatycznej. W wyniku mylnej interpretacji morfologicznej wyrazów w języku angielskim poprzez wzorowanie się na charakterystyce morfologicznej ekwiwalentnych wyrazów w języku polskim uczeń tworzy postać mnogą rzeczowników, które:

- powinny być w liczbie pojedynczej;

* play chesses (poprawnie: chess). PL - szachy - 1. mn.

* I eat a lot of sea fishes. (poprawnie: fish). PL - $\underline{\mathrm{ryb}}-1 . \mathrm{mn}$.

*I buy fresh fruits and vegetables. (poprawnie: fruit). PL - owoce - 1. mn.

- tworzone są nieregularnie;

*I don't like this cottage because there are mouses. (poprawnie: mice)

- tworzone są nieregularnie i już występują w liczbie mnogiej.

*American childrens don't have to learn so much. (poprawnie: children)

*I don't know many peoples here. (poprawnie: people)

*There were a lot of policemens in the streets. (poprawnie: policemen) 
Logiczną konsekwencją pojawienia się rzeczownika w liczbie mnogiej będzie dopasowanie stosownej formy orzeczenia lub innych elementów. Wyraźna kompilacja transferu i hipergeneralizacji widoczna jest w poniższych przykładach:

*The informations are not good. (poprawnie: information is...)

PL - informacje nie są (l.mn.)

${ }^{*}$ New furnitures cost a lot. (poprawnie: furniture costs...)

PL - meble kosztują (1.mn.)

*I always take too many baggages with me. (poprawnie: too much baggage)

PL - zbyt wiele bagaży (l.mn.)

*Can you give me an advice? (poprawnie: some advice)

PL - porada (l.poj.)

Silny wpływ procesów kognitywnych zauważyć można w wypowiedziach zawierających uogólnienia reguł komplementacji czasownikowych. W języku angielskim orzeczenie może wymagać uzupełnienia określonym typem drugiego czasownika, czyli formą podstawową (I can dance), formą bezokolicznikową (I want to go home), imiesłowem współczesnym (I love reading books) lub zdaniem podrzędnym (I suggest that you should visit a doctor). Niektóre $\mathrm{z}$ tych komplementacji będą również wymuszały zastosowanie obowiązkowego przyimka lub dopełnienia (They told me to stay away).

Fałszywa analogia reguły dla komplementacji bezokolicznikowych (np. We have to go) występujących po zwykłych czasownikach (niemodalnych) jest odpowiedzialna za błąd w zdaniu *We must to go (poprawnie: We must go). Uczeń, który wcześniej zinternalizował regułę dotyczącą występowania bezokolicznika to go, ignoruje fakt, że komplementacje po czasownikach modalnych nie podlegają tej regule, a wymagają zwykle użycia formy podstawowej czasownika (go). Z kolei błędna wypowiedź *Every day she reminds me to do my homework. (poprawnie: ... that I should do ...; PL - Codziennie przypomina mi, żeby odrobić prace domową) jest łudząco podobna do innej podobnej konstrukcji (tym razem prawidłowej) Every day she tells me to do my homework. Hipergeneralizacja jest tu powiązana $z$ transferem językowym, co tworzy niezwykle silny efekt fosylizacyjny. Każdy z przypadków błędnych wypowiedzi poniżej 
zawiera uogólnienie reguł stosowania drugiego czasownika, a wpływ języka polskiego objawia się poprzez analogie do polskiego modelu syntaktycznego:

* I suggested him to go to the cinema. (poprawnie: I suggested that he go.)

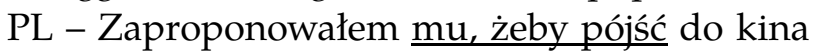

*I dream to be a detective. (poprawnie: I dream of being a detective.) PL - Marzę, aby być detektywem.

*I suggest to invite our classmates. (poprawnie: I suggest inviting our classmates.)

PL - Sugeruję, żeby zaprosić kolegów z klasy.

Przedstawione typy błędnych struktur, których źródło leży we współdziałających mechanizmach hipergeneralizacji oraz transferu językowego, nie obejmują całości omawianego zjawiska, niemniej jednak wskazują na najbardziej uciążliwe przypadki fosylizacji wyekscerpowane z korpusu badawczego.

\section{PODSUMOWANIE}

W interjęzyku Polaków uczących się języka angielskiego na poziomie szkoły ponadgimnazjalnej łatwo można odnaleźć struktury leksykalno-gramatyczne, reguły i zjawiska językowe, które zaprzestały się rozwijać, ustabilizowały się i, mimo dobrej woli uczniów i działań metodyczno-dydaktycznych nauczycieli, pozostały w niezmienionym kształcie wobec języka docelowego. Potwierdzają to przeprowadzone przez autorkę badania, które dowodzą występowania permanentnie utrwalonych błędnych elementów lingwistycznych systematycznie powtarzających się w zebranym materiale $\mathrm{w}$ czteroletnim okresie badawczym. Zaprzestanie rozwoju pewnych kompetencji nastąpiło pomimo ciągłej i jakościowej ekspozycji ucznia na dostarczany przez nauczyciela materiał dydaktyczny. Skoro przyczyn tych błędów nie można doszukiwać się w niestosownych technikach nauczania czy niedostatecznej ilości ćwiczeń wdrażających czy automatyzujących, pozostaje założyć działanie procesów inter- oraz intraferencyjnych.

Dogłębna analiza niepoprawnych struktur wyekscerpowanych z materiału badawczego wskazuje, że we wszystkich omówionych przypad- 
kach działa mechanizm transferu językowego objawiający się błędami interferencji interlingwalnej. Silne oddziaływanie języka ojczystego uczniów jest najbardziej niebezpiecznym procesem kognitywnym skutkującym stabilizacją pewnych kompetencji językowych. Szczególnie często transfer objawia się jako kalka syntaktyczna związana z przeniesieniem polskich zasad pozycjonowania wyrazów w wypowiedzi i dosłownym tłumaczeniu wyrazów na język angielski słowo-po-słowie. Kluczowym elementem analizy jest stwierdzenie występowania w pewnych badanych strukturach dwóch procesów poznawczych łącznie. Unifikacja transferu z symplifikacją lub transferu $\mathrm{z}$ hipergeneralizacją stabilizuje niepoprawne formy na poziomie permanentnym.

Redukcja przynajmniej jednego z czynników występujących w tandemie, a szczególnie baczna obserwacja wpływów międzyjęzykowych daje pewne szanse na destabilizację struktur interjęzyka oraz opóźnienie trwałej fosylizacji. Dokładna diagnoza czynników zaburzających proces akwizycji oraz analiza błędów inspirowana zasadą multiplikacji efektów mogą być skutecznym narzędziem w walce o ciągły rozwój kompetencji językowych ucznia.

\section{BIBILIOGRAFIA}

Adjemian C. (1976), On the nature of interlanguage systems, "Language Learning” 26(2), 297-320.

Arabski J. (2007), Transfer międzyjęzykowy, w: Psychologiczne aspekty dwujęzyczności, red. I. Kurcz, Gdańsk: Gdańskie Wydawnictwo Psychologiczne, s. 341-352.

Bley-Vroman R. (1989), What is the logical problem of foreign language learning?, w: Linguistic Perspective on Second Language Acquisition, red. S. Gass i J. Schachter, Cambridge: CUP, s. 41-68.

Ellis R. (2000), Second Language Acquisition, Oxford: OUP.

Ellis R. (1995), Understanding Second language Acquisition, Oxford: OUP.

Han Z-H. (2003), Fossilization: From Simplicity to Complexity, „International Journal of Bilingual Education and Bilingualism", 6/2, 95-128.

Kellerman E. (1989), The imperfect conditional: fossilization, cross-linguistic influence and natural tendencies in a foreign language setting, $\mathrm{w}$ : Bilingualism across the life span, red. K. Hyltenstam i L. Obler, Cambridge: CUP, s. 87-115.

Komorowska H. (1980), Nauczanie gramatyki języka obcego a interferencja, Warszawa: WSiP.

Larsen-Freeman D. (2006), Second Language Acquisition and the Issue of Fossilization: There Is No End, And There Is No State, w: Studies in Fossilization in Second Language Acquisition, red. Z. Han i T. Odlin, Clevedon: Multilingual Matters, s. $189-200$. 
Lightbown P. (2000), Classroom SLA Research and Second Language Teaching, "Applied Linguistics", 21/4, 431-462.

Lightbown P., Spada N. (1999), How languages are learnt, Oxford: OUP.

Long M. (2003), Stabilization and fossilization in interlanguage development, $\mathrm{w}$ : The Handbook of Second Language Acquisition, red. C. Doughty i M. Long, Oxford: Blackwell, s. 487-536.

Odlin T. (1989), Language Transfer. Cross-linguistic Influence in Language Learning, Cambridge: CUP.

Schachter J. (1990), On the Issues of completeness In Second Language Acquisition, "Second Language Research", 6, 93-124.

Selinker L. (1972), Interlanguage, „IRAL”, 10, 209-231.

Selinker L. (1992), Rediscovering Interlanguage, Londyn: Longman Group UK Limited.

Selinker L. (2006), Afterword:Fossilization 'or' Does Your Mind Mind, w: Studies in Fossilization in Second Language Acquisition, red. Z. Han i T. Odlin, Clevedon: Multilingual Matters, s. 201-210.

Selinker L., Lakshmanan U. (1992), Language Transfer and Fossilization: The Multiple Effects Principle, w: Language Transfer in Language Learning, red. S. Gass i L. Selinker, Amsterdam: John Benjamins Publishing Company, s. 197-216.

Tarone E. (2006), Interlanguage, w: Encyclopedia of Language and Linguistics, red. K. Brown, wyd. IV, Amsterdam: Elsevier Science, s. 1715-1719.

White L. (2003), On the Nature of Interlanguage Representation: Universal Grammar in the Second Language, w: The Handbook of Second Language Acquisition, red. C.J. Doughty i M.H. Long, Oxford: Blackwell Publishing, s. 19-39.

Zybert J. (1999), Errors in Foreign Language Learning. The Case of Polish Learners of English, Warszawa: Wydawnictwo UW.

\section{PSYCHOLINGUISTIC FACTORS OF FOSSILIZATION IN THE ENGLISH LANGUAGE LEARNING}

\section{Summary}

Fossilization as a unique feature of interlanguage systems manifests itself in the cessation of the development of certain linguistic phenomena that remain unchanged in relation to the target language. Although the vast majority of students' errors evolve towards normal structures and then disappear, some of them stabilize permanently. The purpose of this paper is to try to find the answer to the question: are there any features of persistent fossilization of lexical-grammatical structures in the interlanguage of Polish students learning English? The research material was provided by a study conducted on a group of 15 secondary school students in the years 2013-2016. The four-year study 
consisted of a systematic analysis of language errors that kept appearing in the students' written tasks, regardless of the type and quantity of teaching material provided, the length of the study period, the age of the students and the exposure to a variety of teaching techniques. The author attempts to present the phenomenon of fossilization and its main psycholinguistic factors.

Key words: language error, interference, interlanguage, error stabilization, learning strategies, overgeneralisation, simplification, language transfer 